\title{
Specifics in the operating modes of thermosyphon air heater of steam generators №1 and №2 in TPP "Republika" at fuel switch from coal to natural gas
}

\author{
Iliya Iliev $^{1, *}$, Angel Terziev² ${ }^{2}$ Hristo Beloev ${ }^{3}$, and Christiyan Iliev ${ }^{4}$ \\ ${ }^{1}$ Dept. of Thermotechnics, Hydraulic and Ecology, University of Ruse, Ruse, Bulgaria \\ ${ }^{2}$ Dept. of Power Engineering and Power Machines, Technical University of Sofia, Sofia, Bulgaria \\ ${ }^{3}$ Agrarian and Industrial Department, Ruse University, Ruse, Bulgaria \\ ${ }^{4}$ College of Engineering and Physical Sciences, University of Birmingham, United Kingdom
}

\begin{abstract}
A fuel switch is motivated both by the necessity of increasing energy efficiency and the compliance with the ever-stricter regulations regarding the release of harmful emissions in the environment. In this paper a thorough financial and energy analysis on the fuel switch from coal to natural gas is carried out, in particular with respect to waste heat recovery systems (two phase thermosyphons). As a result of the calculation of the heat transfer coefficients for both fuels, it is established that the system running on natural gas has a lower value, due to the lower air velocity, caused in turn by the lower requirement for excess air. The heat transfer coefficients of the evaporation and condensation zones respectively are established $h_{\text {fgas }}=104.9$ и $h_{\text {air }}=84.9\left(\mathrm{~W} / \mathrm{m}^{2} . \mathrm{K}\right)$ for coal and $h_{\text {fgas }}$ и $h_{\text {air }}=84.7\left(\mathrm{~W} / \mathrm{m}^{2} . \mathrm{K}\right)$ respectively for gas. A numerical study is also carried out and a methodology for the analysis of the efficiency of two phase thermosyphons with complex geometry is presented.
\end{abstract}

\section{Introduction}

In the majority of cases a fuel switch is dictated by: the increase of energy efficiency, compliance with the stricter regulations regarding the release of harmful emissions in the environment; decreased operational costs, a low payback period. The fuel switch itself leads to a number of changes, which most often affect the systems for flue gases discharge. In case waste heat recovery mechanisms are in place along the path of discharging of flue gases, then their operational parameters will also change. This has an impact on both the systems' efficiency as well as on the financial parameters for the proposed waste heat recovery system.

Despite the number of developments in literature, including separate case studies, analysing the effects of a fuel switch itself, there are very few cases in which an analysis of the waste heat recovery systems after a fuel switch has been carried out.

A number of developments exist in literature related to the numerical study of the heat and mass transfer processes in two phase thermosyphons. In [1, 2] a detailed analysis of the processes in a horizontal thermosyphon is presented. The effects of the two-phase flow regime along with the degree of filling of the thermosyphon on the heat and mass transfer processes are examined. In [3] the influencing factors including temperature difference, liquid charge, height difference, and circulation flow resistance on the liquid head have been identified and investigated experimentally. Thermal performance of a two-phase closed thermosyphon with an internal surface roughness is presented in [4]. The study shows a reduction in the evaporator's thermal resistance, an increase in its heat transfer and a reduction of the total thermal resistance. The conclusion is that it is possible for the downcomer to be partially filled with liquid. In [5] and [6] numerical and experimental studies of single and twophase thermosyphons are shown accordingly. The vapour velocity and temperature distributions of the flat twophase thermosyphon are obtained by numerically solving the equations of continuity, momentum and energy. A detailed numerical analysis of the heat and mass transfer processes in a multiphase thermosyphon is presented in [7]. [8] presents a CFD analysis of a two-phase thermosyphon using the commercial software ANSYSCFX. The software successfully predicted the overall temperature distribution for the investigated thermosyphon at three different heat inputs.

\section{General information}

Steam generators №1 and №2 were designed and built at the end of the 1940s in ČKD Dukla (former Czechoslovakia) and put into operation in 1951 and 1952 respectively with the project fuel "an energy mixture from the Pernik central enrichment factory" with the following technical characteristics: Moisture content - $W^{r}=16 \%$;

\footnotetext{
*Corresponding author: iki@uni-ruse.bg
} 
Ash content - $A^{r}=43 \%$; Lower Heating Value $Q^{r}=10500 \mathrm{~kJ} / \mathrm{kg}$.

The quality of the operational fuel has continuously worsened in the period 1951-2001 with its lower heating value (LHV) decreasing from 10500 to $8150 \mathrm{~kJ} / \mathrm{kg}$.

In the year 2000 during a planned reconstruction of steam generators №1 and №2 two air heaters of a thermosyphons type based on patent №745/01.06.2005 heat exchanger with heat pipes were realized [9].

On assignment by "Toplofikacija - Pernik" EAD a project was developed and carried out to install an additional air heater with "thermosyphons" (AH-TS) for steam generators №1 and №2 in the TPP. The aim of this project was the reduction of the temperature of exit gases from $220^{\circ} \mathrm{C}$ to $180^{\circ} \mathrm{C}$ and thus the increase in steam generator efficiency in about $2-2.5 \%$.

The air heater consists of 1710 tubes (second hand economiser tubes) with a diameter $\mathrm{d}=32 / 4 \mathrm{~mm}$, placed on two sides, 9 tubes in a row along the height of the gas tract. The tubes are arranged to form a corridor, their total length being $7 \mathrm{~m}$. The evaporation zone of the thermosyphon is $3 \mathrm{~m}$ and inclined at 30 degrees in the direction of the flue gasses, the adiabatic zone is $2 \mathrm{~m}$, inclined at 30 degrees to the evaporation zone, and the condensation zone also $2 \mathrm{~m}$ in length, inclined at 30 degrees to the adiabatic zone.

Chemically treated water filling about $25-30 \%$ of the volume of the tube at lower than atmospheric pressure $\left(p_{v a c}=950\right.$ mbar; $p_{a b s}=1015-950=65$ mbar $)$ is used as working fluid. One of the steam generators was in use until 2009 after which it was shut down as it did not comply with the ecological norms of Directive 2001/80/EC for the limitation of emissions of dust, nitrous and sulphurous oxides, and carbon dioxide from large combustion plants.

Steam generator №2 has changed its fuel base from coal to natural gas without any reconstruction aiming to change the heating surfaces taking place. The reasons behind this being that it has only been used in emergency situation, thus investments in reconstruction were not economically viable.

This circumstance allows us to perform valuable research into the modes of operation of the air heaters, using coal and natural gas respectively. Table 1 represents characteristics of the operational fuels of both steam generators as well as the relevant technical parameters of the air heaters in their respective modes of operation. The data shown in table 1 show a higher efficiency of steam generator №2 in natural gas mode of operation, owing to the possibility of a more in-depth cooling of the flue gases. The end effect however, expressed by the relative increase of the efficiency $\Delta \eta$ when using an air heater with thermosyphons and coal is higher $\Delta \eta=2.72$ compared with $\Delta \eta=2.43$ for natural gas. This is due to the fact that in the boilers using solid fuel the efficiency $\left(\eta{ }^{\prime}=84.8 \%\right)$ without the presence of an air heater is significantly lower than the efficiency of a boiler burning gas $(\eta '=88.6 \%)$ at the same conditions.

Regarding the economic viability, using an air heater with thermosyphons on gas leads to significantly higher cost benefits and hence a shorter pay-back period compared with that of solid fuel, due to the notably higher price of natural gas.

An assessment of the reduction of $\mathrm{CO}_{2}$ emissions as a result of the economies of both hard and gas fuels was carried out. From the results presented in table 1 it is apparent that a more considerable reduction of $\mathrm{CO}_{2}$ emissions is exhibited by an air heater with thermosyphons operating using solid fuel.

The visual observation of the thermosyphons' heating surfaces show low levels of wear subjected to the abrasive action of the coal dust as a result of the 9-year operation of the steam generator, during which time the main fuel used was high ash content sub-bituminous coal. It must be noted however that the structural integrity of the thermosyphons, in particular with regard to leaks, has not been compromised, owing to the fact that they have been manufactured using second hand thick-walled economizer tubes.

\section{Experimental study}

The aim of the experimental studies is to establish whether the 18-year operation of steam generator №2 (9 years of which using sub-bituminous coal, and the remaining 9 operating on natural gas) have had an effect on its efficiency and to what extent the operational data (table 2) correspond to the calculated characteristics presented in table 1 .

Numerous experimental studies regarding the efficiency of the suggested two-phase thermosyphons have been carried out at different regimes of steam boiler operation. The air heater measurements have been carried out in 2008 and 2015, when the steam generator, the characteristics of which are shown in table 1, was burning coal fuel (2008) and natural gas subsequently (2015) (see table 1).

During the experiments, the following were measured at multiple points along the flue gases and the air paths: the air temperature before AH-TS; the temperature of the flue gases before AH-TS; the temperature of the flue gases after AH-TS; the steam generator's nominal load (table 2) (figure 1). The average temperatures of the parameters measured is given in the last column of table 2. The heat transfer coefficients in the evaporation and condensation zones have been determined analytically by means of the normative method used in [10] with corrections made in accordance with the angles of inclination of the thermosyphons. Using the aforementioned methodology we obtain the heat transfer coefficients of the evaporation and condensation zones respectively $\alpha_{\text {fgas }}=104.9$ и $\alpha_{\text {air }}=84.9\left(\mathrm{~W} / \mathrm{m}^{2} . \mathrm{K}\right)$ for coal and $\alpha_{\text {fgas }}=99.7$ and $\alpha_{\text {air }}=84.7\left(\mathrm{~W} / \mathrm{m}^{2} . \mathrm{K}\right)$ respectively for gas. The lower values of the convective heat transfer coefficients are explained with the lower velocities of the gas stream in the intratubular space when using natural gas, due to the lower excess air coefficient compared to that of solid fuel.

From the experimental results in table 2 we can conclude that the measured temperatures (table 2) correspond very closely to the calculated values (table 1). 
Table 1. Technical and economic parameters of the steam boiler and AH-TS.

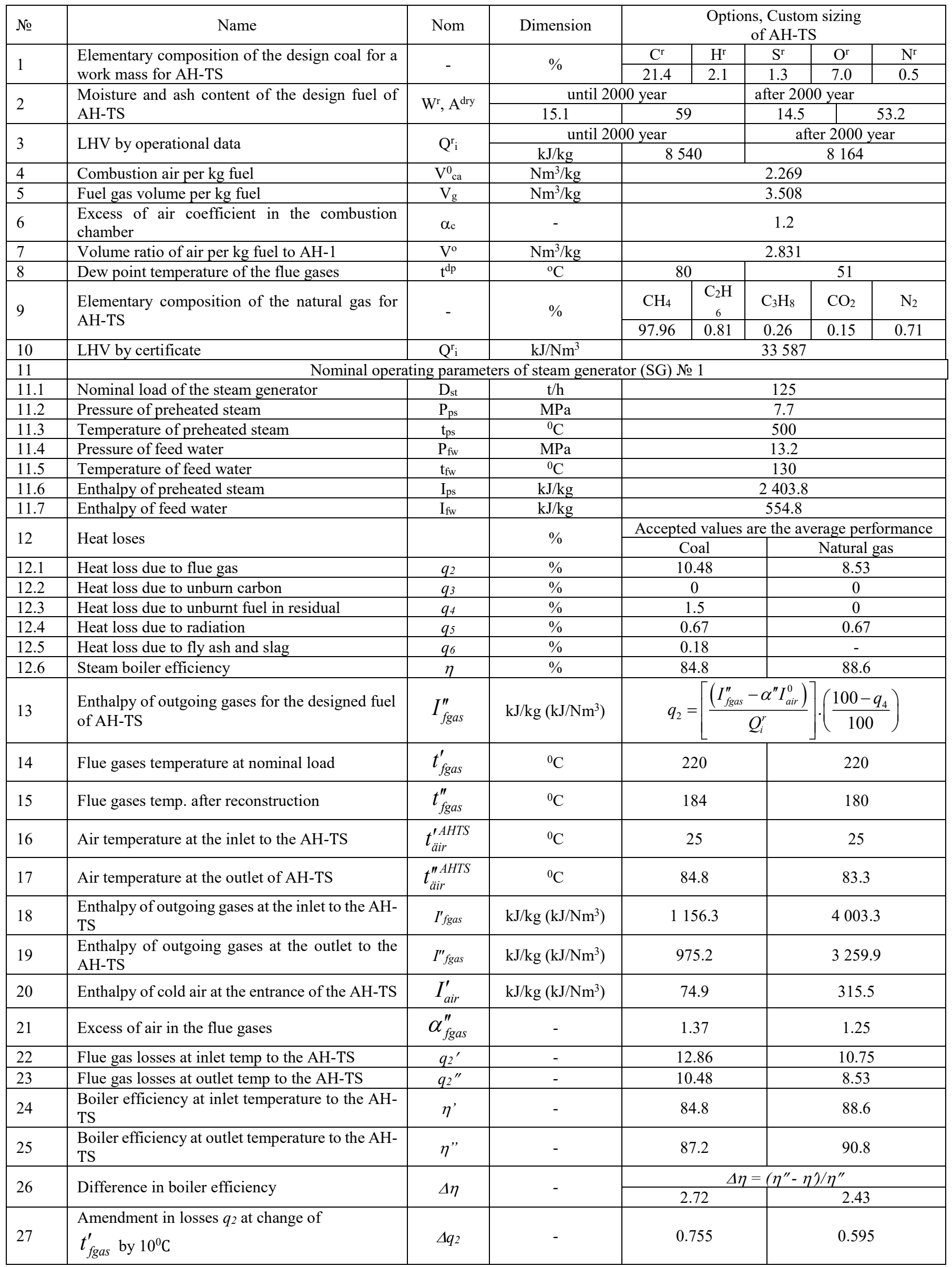




\begin{tabular}{|c|c|c|c|c|c|}
\hline 28 & $\begin{array}{l}\text { Determination of fuel consumption at inlet } \\
\text { temperature to the AH-TS }\end{array}$ & $B^{\prime}$ & $\begin{array}{c}\mathrm{t} / \mathrm{h} \\
\left(\mathrm{Nm}^{3} / \mathrm{h}\right)\end{array}$ & 50343 & 11969 \\
\hline 29 & $\begin{array}{l}\text { Determination of fuel consumption at outlet } \\
\text { temperature to the AH-TS }\end{array}$ & $B^{\prime \prime}$ & $\begin{array}{c}\mathrm{t} / \mathrm{h} \\
\left(\mathrm{Nm}^{3} / \mathrm{h}\right)\end{array}$ & 48972 & 11678 \\
\hline 30 & Fuel savings at nominal load & $\Delta B$ & $\begin{array}{c}\mathrm{t} / \mathrm{h} \\
\left(\mathrm{Nm}^{3} / \mathrm{h}\right) \\
\end{array}$ & 1371 & 291 \\
\hline 31 & Annual usage of the boiler \#1 & $\tau$ & $\mathrm{h} /$ year & \multicolumn{2}{|c|}{4800} \\
\hline 32 & Annual fuel savings & $B$ & $\begin{array}{c}\text { t/year } \\
\left(10^{3} \mathrm{Nm}^{3} / \text { year }\right) \\
\end{array}$ & 6580 & 1397 \\
\hline 33 & Fuel price & $P_{f}$ & $\begin{array}{c}\mathrm{EUR} / \mathrm{t} \\
\left(\mathrm{EUR} / 10^{3} \mathrm{Nm}^{3}\right)\end{array}$ & 12.59 & 254.85 \\
\hline 34 & Price of electrical energy & $P_{e l}$ & EUR/kWh & \multicolumn{2}{|c|}{0,08} \\
\hline 35 & Annual cash savings & $L_{a n}$ & EUR/year & 82842 & 356025 \\
\hline 36 & Electrical energy consumption for coal milling & $E$ & $\mathrm{kWh} / \mathrm{t}$ & 25 & - \\
\hline 37 & Annual savings of electrical energy & $L_{e l-s}$ & $\mathrm{kWh} /$ year & 164500 & - \\
\hline 38 & Annual cash savings of electrical energy & Lan-el & EUR/year & 13160 & - \\
\hline 39 & Total annual cash savings & $\begin{array}{l}L_{a n}+L_{a n-} \\
\quad e l\end{array}$ & EUR/year & 96002 & 356025 \\
\hline 40 & Total heating surface of AH-TS & $A_{\text {total }}$ & $\mathrm{m}^{2}$ & \multicolumn{2}{|c|}{860} \\
\hline 41 & Total mass of AH-TS & $G$ & $\mathrm{~kg}$ & \multicolumn{2}{|c|}{26144} \\
\hline 42 & Total costs of implementation of AH-TS & $L_{\text {total }}$ & EUR & \multicolumn{2}{|c|}{185000} \\
\hline 43 & Payback period & $P B$ & year & 1.93 & 0.52 \\
\hline 44 & $\mathrm{CO}_{2}$ emission factor & $E F_{C O 2}$ & $\begin{array}{c}\mathrm{t} \mathrm{CO} / \mathrm{t} \\
\left(\mathrm{t} \mathrm{CO}_{2} / 10^{3} \mathrm{Nm}^{3}\right) \\
\end{array}$ & 0.789 & 1.996 \\
\hline 45 & $\mathrm{CO}_{2}$ emission reduction & & $\mathrm{t} /$ year & 5192 & 2788 \\
\hline
\end{tabular}

Table 2. Experimental data.

\begin{tabular}{|c|c|c|c|c|c|c|c|}
\hline \multirow{2}{*}{ Parameter } & \multirow{2}{*}{\multicolumn{2}{|c|}{ Label }} & \multicolumn{5}{|c|}{ Trial } \\
\hline & & & 1 & 2.. &. .23 & 24 & Average \\
\hline \multirow{2}{*}{ Air temperature before $\mathrm{AH}-\mathrm{TS},{ }^{0} \mathrm{C}$} & \multirow{2}{*}{$t_{\text {air }}^{\prime A H-T S}$} & coal & 25 & 23.6 & 24.8 & 26.2 & 25.0 \\
\hline & & natural gas & 22.6 & 24.2 & 24.8 & 25.1 & 24.2 \\
\hline \multirow{2}{*}{ Air temperature after $\mathrm{AH}-\mathrm{TS},{ }^{0} \mathrm{C}$} & \multirow{2}{*}{$t_{\text {air }}^{\prime \prime A H-T S}$} & coal & 84.8 & 81.7 & 73.0 & 80.2 & 81.2 \\
\hline & & natural gas & 84.6 & 83.7 & 83.9 & 86.3 & 84.6 \\
\hline \multirow[t]{2}{*}{ Flue gas temperature before $\mathrm{AH}-\mathrm{TS},{ }^{0} \mathrm{C}$} & \multirow{2}{*}{$t_{\text {fgas }}^{\prime}$} & coal & 219.5 & 214 & 218 & 217.5 & 218.4 \\
\hline & & natural gas & 222.5 & 218.8 & 216.4 & 220.5 & 219.6 \\
\hline \multirow{2}{*}{ Flue gas temperature after $\mathrm{AH}-\mathrm{TS},{ }^{0} \mathrm{C}$} & \multirow{2}{*}{$t_{f g a s}^{\prime \prime}$} & coal & 184.3 & 179 & 189 & 185 & 184.9 \\
\hline & & natural gas & 180.2 & 178.1 & 177.1 & 178.5 & 178.5 \\
\hline \multirow[t]{2}{*}{ Steam generator load, $\mathrm{t} / \mathrm{h}$} & \multirow{2}{*}{$\mathrm{D}_{\mathrm{s}}$} & coal & 122.5 & 118 & 121 & 123 & 121 \\
\hline & & natural gas & 120 & 122.4 & 118.9 & 114.6 & 119 \\
\hline
\end{tabular}

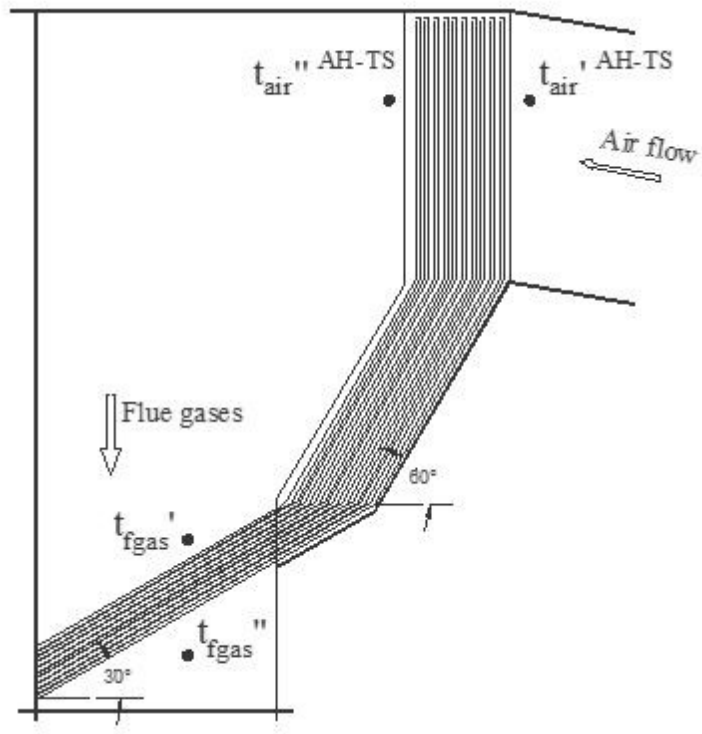

Fig. 1. Location of the parameters measured.

\section{Numerical study}

The numerical study aims to show its applicability to the analysis of two phase thermosyphons after a change in the operational regime parameters. The experimental studies carried out will allow the validation of the results from the numerical solution and the creation of a methodology for the analysis of the efficiency of the systems specified.

\subsection{Geometric model of the waste heat recovery system}

For the aims of the numerical study a 3D model has been created (Figure 2). The air heater consists of 95 tubes in a row, placed on two sides, and 9 tubes in height, arranged in a square tube layout. Each tube's diameter is $d=32 / 4$ $\mathrm{mm}$, the longitudinal tube pitch $\mathrm{s}_{1}=42 \mathrm{~mm}$; the transverse tube pitch between the tubes $\mathrm{s}_{2}=45 \mathrm{~mm}$. The evaporation zone of the thermosyphon is $3 \mathrm{~m}$, the adiabatic one $2 \mathrm{~m}$, and the condensation zone $2 \mathrm{~m}$. The two-meter adiabatic zone is located between the evaporation and the 
condensation zones, and it is further isolated with perlitoconcrete. The aerodynamic resistances are as follows: on the gases part $303 \mathrm{~Pa}$, on the air $219 \mathrm{~Pa}$.

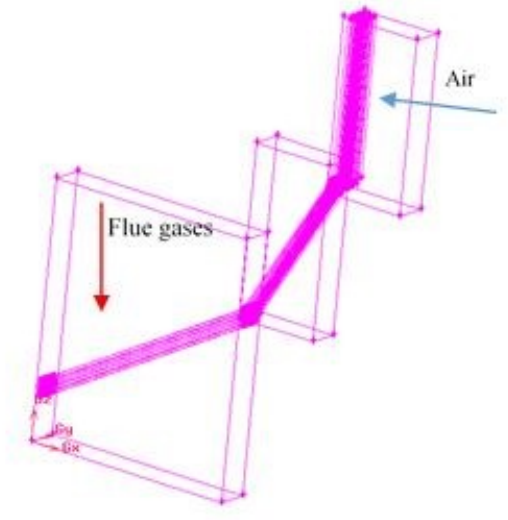

Fig. 2. Location of the parameters measured 3D Model of the selected unit, part of the air heater.

For the purposes of the numerical study, a threedimensional model was created. The model consists of 6 rows with 5 pipes inclined at $30^{\circ}$ for each zone of the air heater. The dimensions, thickness and distance between pipes are presented above. A meshing procedure for the proposed volume has been applied, whereby 1250000 pcs. triangle mesh elements have been created.

\subsection{Mathematical modeling}

Two different types of heat transfer processes were identified - in the two-phase thermosyphon and between a thermosyphon and flue gases and air. It was considered that a steady state heat transfer is reached in the two-phase thermosyphon. The results obtained were further used as input data for the study of the heat transfer between air heater and flue gases and air.

The numerical solution of the heat transfer processes between the air heater and the flue gases and air is based on the continuity equation, momentum equation and energy equation combined with the appropriate turbulent model. Turbulence modelling is based on the Reynold Averaged Navier Stokoes Equations (RANS). The Finite Volume Method (FVM) was used for the numerical solution of RANS. The fundamental equations were derived in the FVM using the integral approach. The numerical solution procedure is presented in Figure 3. The equations that are solved during the numerical procedure are as follows [11].

\subsection{Initial conditions}

Numerical procedures were carried out to analyze the heat transfer processes between the air heater and the flue gas and air via the paths of the two tracts, considering both fuel bases - coal and natural gas. Furthermore, the adiabatic zone of the thermosyphon air heater is considered. The experimental data shows that the velocity of the flue gases ( $\mathrm{w}_{\text {fgas }}$ ) before the air heater is about 7.8 $\mathrm{m} / \mathrm{s}$, and the velocity of the air before the air heater is 5.6 $\mathrm{m} / \mathrm{s}$. (when the boiler is running on coal). The influence of the heat transfer coefficient $(h)$ was investigated. Initial parameters for the numerical procedures are presented in Table 3 .

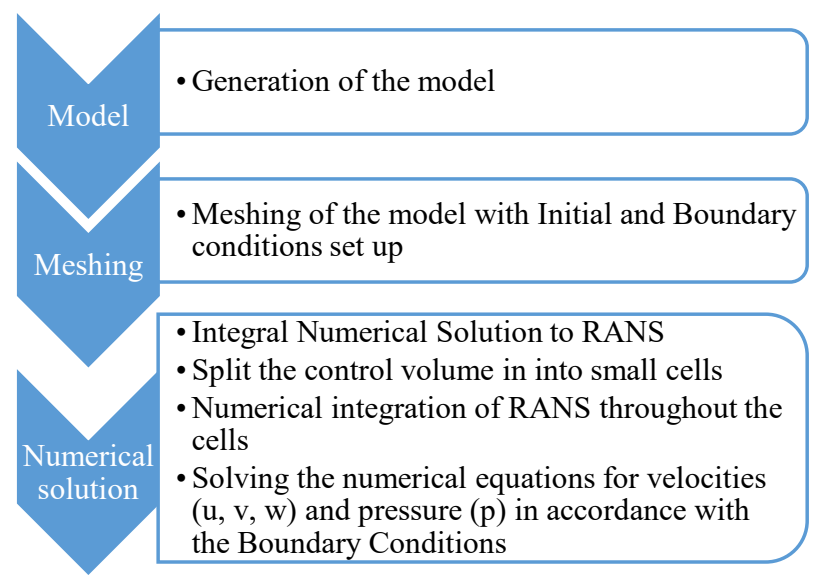

Fig. 3. Block-scheme of the selected numerical procedure.

Table 3. Experimental data.

\begin{tabular}{|c|c|c|c|c|}
\hline \multirow{2}{*}{ Parameter } & \multirow{2}{*}{ Label } & \multicolumn{3}{|c|}{ Mode } \\
\hline & & 1 & 2 & 3 \\
\hline $\begin{array}{l}\text { Air temp. before } \mathrm{AH}-\mathrm{TS},{ }^{\circ} \mathrm{C} \\
\text { (coal) }\end{array}$ & tair'AH-TS & 25.0 & 25.0 & 25.0 \\
\hline $\begin{array}{l}\text { Air temp. before } \mathrm{AH}-\mathrm{TS},{ }^{\circ} \mathrm{C} \\
\text { (natural gas) }\end{array}$ & tair'AH-TS & 24.2 & 24.2 & 24.2 \\
\hline Air temp. after AH-TS, ${ }^{\circ} \mathrm{C}$ (coal) & $\mathrm{t}_{\text {air }}{ }^{\mathrm{AH}-\mathrm{TS}}$ & 81.2 & 81.2 & 81.2 \\
\hline $\begin{array}{l}\text { Air temp. after } \mathrm{AH}-\mathrm{TS},{ }^{\circ} \mathrm{C} \\
\text { (natural gas) }\end{array}$ & $t_{\text {air }}$ "AH-TS & 84.6 & 84.6 & 84.6 \\
\hline $\begin{array}{l}\text { Flue gas temp. before AH-TS, } \\
{ }^{\circ} \mathrm{C} \text { (coal) }\end{array}$ & $t^{\prime}$ 'gas & 218.4 & 218.4 & 218.4 \\
\hline $\begin{array}{l}\text { Flue gas temp. before } \mathrm{AH}-\mathrm{TS}, \\
{ }^{\circ} \mathrm{C} \text { (natural gas) }\end{array}$ & $t_{\text {fgas }}^{\prime}$ & 219.6 & 219.6 & 219.6 \\
\hline $\begin{array}{l}\text { Flue gas temp. after AH-TS, }{ }^{\circ} \mathrm{C} \\
\text { (coal) }\end{array}$ & $t^{\prime \prime g a s}$ & 184.9 & 184.9 & 184.9 \\
\hline $\begin{array}{l}\text { Flue gas temp. after } \mathrm{AH}-\mathrm{TS},{ }^{\circ} \mathrm{C} \\
\text { (natural gas) }\end{array}$ & $t^{\prime \prime}$ fgas & 178.5 & 178.5 & 178.5 \\
\hline $\begin{array}{l}\text { Heat transfer coefficient } \\
\text { (evaporation zone), } \mathrm{W} /\left(\mathrm{m}^{2} . \mathrm{K}\right) \\
\text { (coal) }\end{array}$ & $h_{e v}$ & 92 & 105 & 116 \\
\hline $\begin{array}{l}\text { Heat transfer coefficient } \\
\text { (evaporation zone), } \mathrm{W} /\left(\mathrm{m}^{2} . \mathrm{K}\right) \\
\text { (natural gas) }\end{array}$ & $h_{e v}$ & 89 & 100 & 110 \\
\hline $\begin{array}{l}\text { Heat transfer coefficient } \\
\text { (condenser zone), } \mathrm{W} /\left(\mathrm{m}^{2} . \mathrm{K}\right) \\
\text { (coal) }\end{array}$ & $h_{c o n}$ & 74 & 85 & 104 \\
\hline $\begin{array}{l}\text { Heat transfer coefficient } \\
\text { (condenser zone), } \mathrm{W} /\left(\mathrm{m}^{2} \cdot \mathrm{K}\right) \\
\text { (natural gas) }\end{array}$ & $h_{c o n}$ & 75 & 85 & 105 \\
\hline
\end{tabular}

\subsection{Results}

Fig. 4 and 5 depict information on the distribution of the temperatures of the gases passing through the two phase thermosyphon. From the figures, it is apparent that the decrease of temperatures at natural gas is lower because of the lower gas phase flow (approx. 1\%).

Fig. 6 and 7 depict the velocity field distribution at both fuel bases. We observe that the velocities of the gas in the intratubular space when using natural gas are lower, 
which is the reason behind the weaker heat exchange, respectively the lower degree of waste heat recovery.

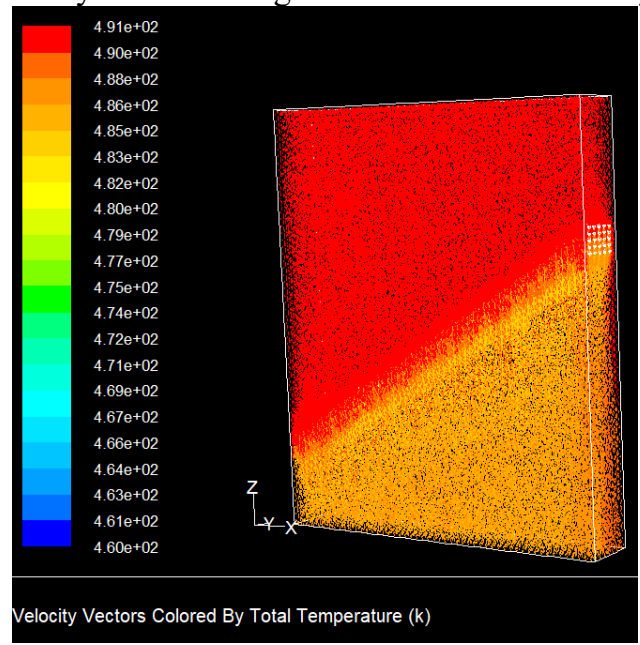

Fig. 4. Flue gases temperature field distribution (coal fuel base).

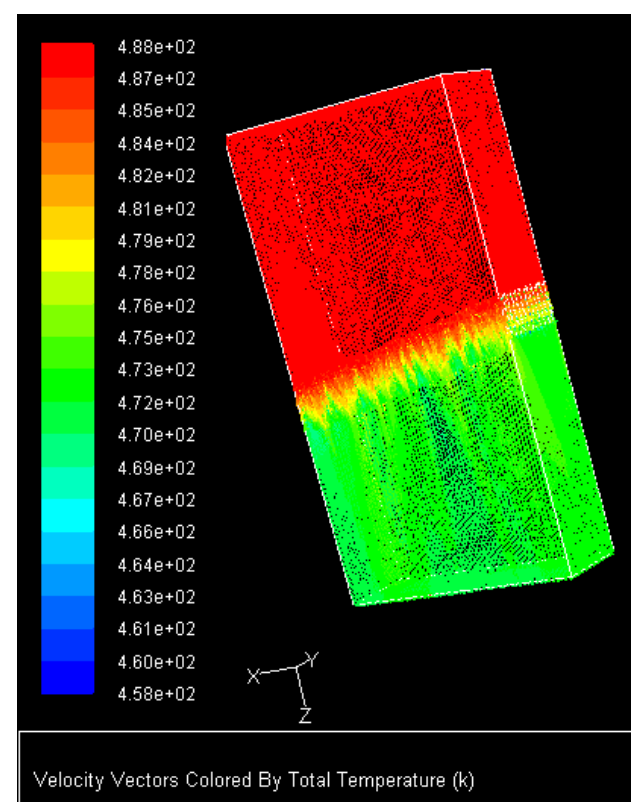

Fig. 5. Flue gases temperature field distribution (natural gas fuel base).

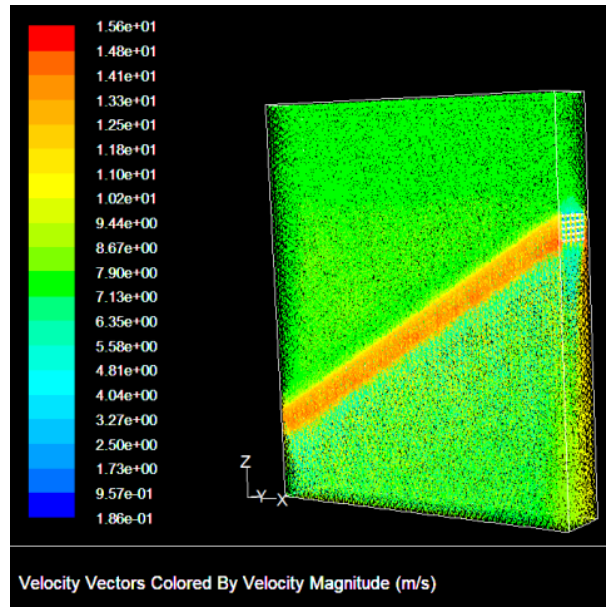

Fig. 6. Flue gases velocity field distribution (coal fuel base).

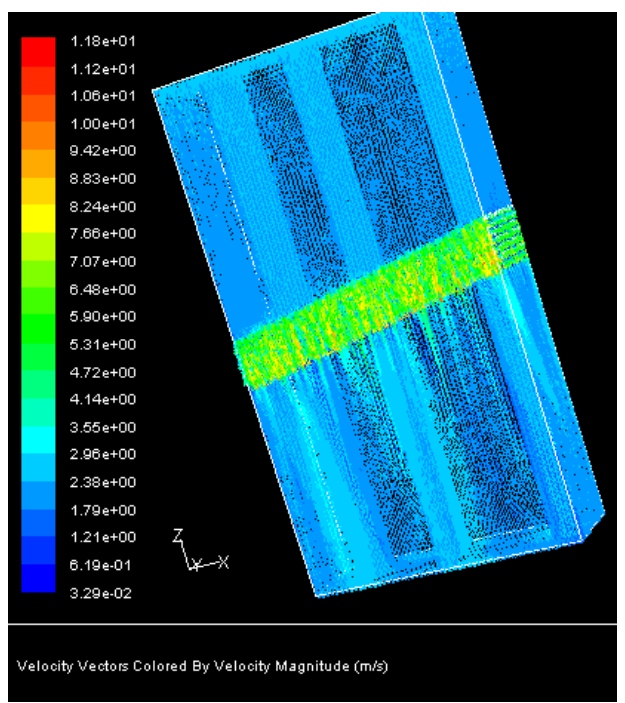

Fig. 7. Flue gases velocity field distribution (natural gas fuel base).

In addition, the numerical analyses show that the degree of turbulence in the intratubular space (around the two phase thermosyphons) increases by about $200 \%$, which is a reason for the intensive heat exchange.

Table 4 presents a summary of the results of the numerical analysis.

Table 4. Numerical procedure results.

\begin{tabular}{|l|c|c|c|c|c|}
\hline \multicolumn{1}{|c|}{$\begin{array}{c}\text { Numerical procedure case } \\
\text { number }\end{array}$} & $\mathrm{t}^{\prime}$ flugas & $\mathrm{t}^{\prime \prime}$ 'llugas & $\mathrm{w}_{\text {fluegas }}$ & $\mathrm{t}_{\text {air }}$ & $\mathrm{W}_{\text {air }}$ \\
\cline { 2 - 6 }${ }^{\circ} \mathrm{C}$ & ${ }^{\circ} \mathrm{C}$ & $\mathrm{m} / \mathrm{s}$ & ${ }^{\circ} \mathrm{C}$ & $\mathrm{m} / \mathrm{s}$ \\
\hline $\begin{array}{l}\mathrm{TI}-10 \%, h_{\text {gas }}=92, h_{\text {air }}=74, \\
\mathrm{~W} /\left(\mathrm{m}^{2} \mathrm{~K}\right)(\text { coal })\end{array}$ & 179 & 153.7 & 14.1 & 79.5 & 9.56 \\
\hline $\begin{array}{l}\mathrm{TI}-10 \%, h_{\text {gas }}=89, h_{\text {air }}=75, \\
\mathrm{~W} /\left(\mathrm{m}^{2} \mathrm{~K}\right)(\text { natural gas })\end{array}$ & 181 & 150.8 & 13.0 & 82.5 & 8.4 \\
\hline $\begin{array}{l}\mathrm{TI}-10 \%, h_{\text {gas }}=105, h_{\text {air }}=85, \\
\left(\mathrm{~W} / \mathrm{m}^{2} \mathrm{~K}\right)(\text { coal })\end{array}$ & 218.8 & 185.5 & 14.2 & 81.4 & 10.0 \\
\hline $\begin{array}{l}\mathrm{TI}-10 \%, h_{\text {gas }}=100, h_{\text {air }}=85, \\
\left(\mathrm{~W} / \mathrm{m}^{2} \mathrm{~K}\right)(\text { natural gas })\end{array}$ & 219.6 & 179.7 & 12.9 & 85.0 & 9.5 \\
\hline $\begin{array}{l}\mathrm{TI}-10 \%, h_{\text {gas }}=116, h_{\text {air }}=104, \\
\mathrm{~W} /\left(\mathrm{m}^{2} \mathrm{~K}\right)(\text { coal })\end{array}$ & 224.5 & 193.2 & 14.4 & 82.5 & 10.5 \\
\hline $\begin{array}{l}\mathrm{TI}-10 \%, h_{\text {gas }}=110, h_{\text {air }}=105, \\
\mathrm{~W} /\left(\mathrm{m}^{2} \mathrm{~K}\right)(\text { natural gas })\end{array}$ & 226.0 & 188.1 & 13.4 & 86.0 & 9.9 \\
\hline
\end{tabular}

The results show that the difference in temperatures in the two tracts under different regimes do not differ by more than $5 \%$ from the experimental studies. The closest to the results of the experimental study are the $3^{\text {rd }}$ and $4^{\text {th }}$ rows of Table 4.

\section{Conclusion}

The reconstruction of steam boilers №1 and №2 at "Repbulica TPP" with the production, assembly and installation of the additional air heater with thermosyphons carried out was successful and effective the temperature of the exit gases has been reduced on average from 218 to $185^{\circ} \mathrm{C}$ as a consequence. The utilised heat from the flue gases heats the outdoor air from 25 to $81^{\circ} \mathrm{C}$ and thus ensures a non-corrosive regime for the subsequent heating surface along the air tract. 
In our current work the results of the numerical study of heat exchange processes in a thermosyphon air heater are presented, inclined at $30^{\circ}$ along the path of the flue gases, $60^{\circ}$ in the adiabatic zone, and perpendicular along the air path. The influence of the heat transfer coefficient in the zone of evaporation and condensation of the pipes was investigated both for coal and natural gas fuel bases. The presence of an adiabatic zone undoubtedly worsens the heat exchange conditions as a whole owing to unfavourable hydrodynamic conditions, but in the present case due to the location of the flue gas tract and air blower, the presence of such a specified area is inevitable. The heat transfer coefficients of the evaporation and condensation zones are respectively $\alpha_{\text {fgas }}=104.9$ и $\alpha_{\text {air }}=84.9\left(\mathrm{~W} / \mathrm{m}^{2} . \mathrm{K}\right)$ for coal, and $\alpha_{\text {fgas }}=99.7$ and $\alpha_{\text {air }}$ $=84.7\left(\mathrm{~W} / \mathrm{m}^{2} . \mathrm{K}\right)$ for gas.

The results of the numerical analysis have been validated with the experimental ones, in which the maximal margin of error is about $5 \%$. Thus the numerical modelling scheme proposed allows for an express analysis of the efficiency of the existing systems for waste heat recovery using two phase thermosyphons when a fuel switch from coal to natural gas is performed.

\section{References}

1. Wang Y., X. Wang, H. Chen, R. Taylor, Y. Zhu, A Combined CFD/visualized investigation of twophase heat and mass transfer inside a horizontal loop thermosiphon, International Journal of Heat and Mass Transfer, Volume 112, September (2017), Pages 607-619

2. Jouhara H, Fadhl B, Wrobel LC. Three-dimensional CFD simulation of geyser boiling in a two-phase closed thermosiphon, International Journal of Hydrogen Energy, (2016)

3. Zhang P., B. Wang, W. Xianting Li, Experimental Investigation on two-phase thermosiphon loop with partially liquid-filled downcomer, Applied Energy, Vol. 160, (2015), p.p. 10-17

4. Alammar A., F. Al-Mousawai, R. Al-Dadah, S. Mahmoud, R. Hood, Enhancing Thermal performance of a Two-phase Closed Thermosyphon With an Internal Surface Roughness, Journal of Cleaner Production, (2018).

5. Zelzouli K., A. Guizani, C. Kerkeni, Numerical and experimental investigation of thermosyphon solar water heater, Energy Conversion and Management, Vol. 78, 2014, p.p. 913-922

6. Zhongliang M., G. Ma, S. Cheng, Numerical simulation and experimental verification of a flat two-phase thermosyphon, Energy Conversion and Management, Vol. 50, 2009, p.p. 1095-1100.

7. Jouhara H., B. Fadhl, L. Wrobel, Three - dimensional CFD simulation of geyser boiling in a two-phase closed thermosyphon, International Journal of Hydrogen Energy, Vol. 41, Issue 37, October 2016, 16463-16467;
8. Chaudhari N. E., N. Vijra, T. P. Singh, Computational Fluid Dynamics Analysis of TwoPhase Thermosyphon, International Journal of Engineering and Technology (IJET), Vol 5 No 5 OctNov 2013, ISSN: 0975-4024, 3794-3800.

9. Marinov H., Iliev I., Patent № 745/31.01.2002, Heat exchanger with heat pipes, 2005, Patent office of Republic of Bulgaria (in Bulgarian);

10. Thermal calculation of boilers (normative method), third edition, revised and expanded, St. Petersburg, 1998 (in Russian);

11. Fluent 6.3 User's Guide, September, (2006). 